\title{
PERAN PEMERINTAH DESA TERHADAP KELOMPOK TANI KARYA LESTARI DI DESA TALIKURAN SATU KECAMATAN SONDER KABUPATEN MINAHASA
}

\author{
Imelda Manopo \\ Jenny Baroleh \\ Charles R. Ngangi
}

\begin{abstract}
This study aims to determine the role of village government towards of karya lestari farmer group in talikuran one village sub-district of sonder district minahasa. The study lasted for 2 (two) months starting from March to April 2017 in Talikuran satu Village Sub-district of Sonder District of Minahasa ranging from preparation, data retrieval, to the preparation or research reports. Data collection methods in this study using primary data and secondary data. Primary data is obtained directly from the source though surveys and interviews using questionnaires to all members of karya lestari farmer groups, while secondary data is obtained directly from institutions related to the research in village government Talikuran one. The result showed that the role of village government towards sustainable farmer group is categorized as excellent with score in the can is 315.
\end{abstract}

Keywords: $\quad$ role of village government, karya lestari farmer group, Talikuran Satu Village of, Sonder Sub-district of Minahasa District

\begin{abstract}
ABSTRAK
Penelitian ini bertujuan untuk mengetahui peran pemerintah desa terhadap Kelompok Tani Karya Lestari di Desa Talikuran Satu Kecamatan Sonder Kabupaten Minahasa. Penelitian dilaksanakan selama 2 bulan mulai dari bulan Maret 2017 sampai April 2017 mulai dari persiapan, pengambilan data sampai penyusunan laporan hasil penelitian. Metode pengumpulan data menggunakan data primer dan data sekunder. Data primer diperoleh langsung dari sumbernya melalui survei dan wawancara dengan menggunakan daftar pertanyaan kepada semua anggota Kelompok Tani Karya Lestari, sedangkan data sekunder diperoleh dari pemerintah Desa Talikuran Satu. Hasil penelitian menunjukkan bahwa peran pemerintah desa terhadap Kelompok Tani Karya Lestari tergolong dalam kategori sangat baik dengan skor 315.
\end{abstract}

Kata kunci : peran pemerintah desa, Kelompok Tani Karya Lestari, Desa Talikuran Satu Kecamatan Sonder Kabupaten Minahasa.

\section{PENDAHULUAN}

\section{Latar Belakang}

Pemerintah daerah dituntut memberikan pelayanan yang lebih prima serta memberdayakan masyarakat, agar masyarakat ikut terlibat dalam pembangunan untuk kemajuan daerahnya, karena masyarakatlah yang lebih tahu apa yang mereka butuhkan (Susanti, 2015). Melihat hal tersebut, penyelenggaraan otonomi daerah dipandang perlu untuk lebih menekankan pada prinsipprinsip demokrasi, peran serta masyarakat, pemerataan dan keadilan, serta memperhatikan potensi dan keanekaragaman daerah. Sektor pertanian merupakan sektor yang paling 
prospektif dalam menopang perekonomian nasional. Bukti bahwa sektor pertanian adalah sektor yang prosfektif dimana kebutuhan pangan di dalam negeri dari tahun ke tahun semakin meningkat seiring dengan peningkatan jumlah penduduk (Saragih, 2004).

Usaha tani di Indonesia didominasi oleh usaha tani keluarga skala kecil yang sangat lemah dalam berbagai bidang, dengan kata lain tidak dapat berkembang mandiri secara dinamis.Petani kecil sangat tergantung pada golongan petani lahan luas atau pedagang untuk memperoleh aset produktif (lahan dan peralatan), modal kerja dan perolehan sarana produksi.

Kebijakan yang ditempuh pemerintah untuk mewujudkan tujuan pembangunan nasional diantaranya adalah dengan peningkatan kehidupan ekonomi yang dilakukan melalui pembangunan pertanian. Salah satu kebijakan mendasar untuk mengatasi masalah dalam pertanian adalah membentuk kelompok tani.

Kelompok tani adalah kumpulan para petani yang terikat secara non formal atas dasar keserasian, kesamaan kondisi lingkungan (sosial, ekonomi, sumberdaya), keakraban, kepentingan bersama dan saling mempercayai, serta mempunyai pimpinan untuk mencapai tujuan bersama. Pembentukan kelompok tani merupakan suatu usaha pembangunan pertanian yang berfungsi untuk memperlancar hasil pertanian dan memberikan wadah yang kokoh di pedesaan dan merupakan tempat untuk memperkuat kerjasama diantara para petani dalam kelompok untuk menghadapi berbagai macam ancaman, tantangan, hambatan, dan gangguan.

Pertanian merupakan salah satu sektor utama bagi mata pencaharian penduduk di Kabupaten Minahasa. Sehubungan dengan itu maka masyarakat di Desa Talikuran Satu yang berprofesi sebagai petani diberdayakan dengan dibentuknya kelompok tani. Kelompok Tani Karya Lestari adalah kelompok tani yang berkembang di Desa Talikuran Satu dengan mayoritas petani di desa ini bercocok tanam padi dan jagung. Kelompok Tani Karya Lestari mempunyai tujuan bekerja sama dalam mengelolah lahan pertanian dengan baik untuk meningkatkan hasil produksi pertanian yang maksimal sehingga para anggota petani bisa merasakan dampak yang positif bagi kehidupannya yang berujung pada kesejahteraan anggota petani. Kelompok Tani Karya Lestari terbentuk pada tahun 2007 yang beranggotakan 12 orang pengurus (Ketua, Sekretaris, dan Bendahara) 3 orang, jadi total berjumlah 15 orang. Berdasarkan latar belakang yang diuraikan maka penting untuk mengetahui peran pemerintah desa terhadap kelompok tani Karya Lestari di Desa Talikuran Satu Kecamatan Sonder Kabupaten Minahasa.

\section{Rumusan Masalah}

Berdasarkan latar belakang yang telah dikemukakan maka, yang menjadi masalah dalam penelitian ini adalah bagaimana peran pemerintah desa terhadap Kelompok Tani Karya Lestari di Desa Talikuran Satu Kecamatan Sonder Kabupaten Minahasa?

\section{Tujuan Penelitian}

Penelitian ini bertujuan untuk mengetahui peran pemerintah desa terhadap Kelompok Tani Karya Lestari di Desa Talikuran Satu Kecamatan Sonder Kabupaten Minahasa.

\section{Manfaat Penelitian}

Penelitian ini diharapkan dapat memberikan kontribusi kepada para petani terlebih khusus anggota Kelompok Tani Karya Lestari. Dan sebagai bahan masukan dalam pengambilan kebijakan tentang Kelompok Tani.

\section{METODOLOGI PENELITIAN}

\section{Lokasi dan Waktu Penelitian}

Penelitian ini dilaksanakan di Desa Talikuran Satu Kecamatan Sonder Kabupaten Minahasa selama 2 bulan mulai dari bulan Maret 2017 sampai bulan April 2017 mulai dari persiapan, pengambilan data sampai pada penyusunan laporan hasil penelitian. 


\section{Metode Pengumpulan Data}

Metode pengumpulan data dalam penelitian ini menggunakan data primer dan data sekunder. Data primer diperoleh langsung dari sumbernya melalui survei dan wawancara dengan menggunakan daftar pertanyaan kepada semua anggota Kelompok Tani Karya Lestari, sedangkan data sekunder diperoleh dari lembaga yang terkait dengan penelitian yaitu pemerintah Desa Talikuran Satu.

\section{Teknik Pengambilan Data}

Teknik pengambilan data dilakukan dengan mengikutsertakan semua anggota Kelompok Tani Karya Lestari, dengan jumlah responden sebanyak 15 orang yang terdiri dari Ketua, sekretaris, bendahara dan 12 orang anggota kelompok.

\section{Konsep Pengukuran Variabel}

Indikator penelitian yang dikaji dalam penelitian ini yaitu :

1. Karakteristik Kelompok Tani
1) Nama Kelompok Tani
2) Tahun Terbentuk
3) Keanggotaan
4) Lahan yang digunakan
5) Jenis Usaha

2. Karakteristik Responden

1) Umur anggota Kelompok Tani (dalam tahun)

2) Tingkat Pendidikan formal

3) Pekerjaan

3. Pengukuran peran pemerintah desa terhadap kelompok tani :

a. Peran dalam hasil pemasaran tanaman, dengan skor :

1. Peran dalam hasil pemasaran tanaman, baik $=3$

2. Peran dalam pengolahan pemasaran tanaman, cukup baik $=2$

3. Peran dalam hasil pemasaran tanaman, tidak baik $=1$

b. Peran dalam menghadiri pertemuan/ musyawarah yang diselenggarakan oleh kelompok tani, dengan skor :
1. Peran dalam menghadiri pertemuan/musyarawah yang diselenggarakan oleh kelompok tani, baik $=3$
2. Peran dalam menghadiri pertemuan/musyawarah yang diselenggarakan oleh kelompok tani, cukup baik $=2$
3. Peran dalam menghadiri pertemuan/musyawarah yang diselenggarakan oleh kelompok tani, tdak baik= 1

c. Peran menyampaikan informasi tukar menukar pikiran dalam berusaha tani, dengan skor :

1. Peran menyampaikan informasi tukar menukar pikiran dalam berusaha tani, baik $=3$

2. Peran menyampaikan informasi tukar menukar pikiran dalam berusaha tani, cukup baik $=2$

3. Peran menyampaikan informasi tukar menukar pikiran dalam berusaha tani, tidak baik $=1$

d. Peran dalam mengajarkan berbagai ketrampilan usaha tani kepada anggota kelompok, dengan skor :

1. Peran dalam mengajarkan berbagai ketrampilan usaha tani kepada anggota kelompok, baik $=3$

2. Peran dalam mengajarkan berbagai ketrampilan usaha tani kepada anggota kelompok, cukup baik $=2$

3. Peran dalam mengajarkan berbagai ketrampilan usaha tani kepada anggota kelompok, tidak baik $=1$

e. Membantu para petani dalam memecahkan suatu masalah dalam berusaha tani, dengan skor:

1. Membantu para petani dalam memecahkan suatu masalah dalam berusaha tani, baik $=3$

2. Membantu para petani dalam memecahkan suatu masalah dalam berusaha tani, cukup baik $=2$ 
3. Membantu para petani dalam memecahkan suatu masalah dalam berusaha tani, tidak baik $=1$

f. Peran pemerintah desa dalam melakukan pencatatan mengenai keanggotaan kelompok tani yang berkembang, dengan skor :

1. Peran pemerintah desa dalam melakukan pencatatan mengenai keanggotaan kelompok tani yang berkembang, baik $=3$

2. Peran pemerintah desa dalam melakukan pencatatan mengenai keanggotaan kelompok tani yang berkembang, cukup baik $=2$

3. Peran pemerintah desa dalam melakukan pencatatan mengenai keanggotaan kelompok tani yang berkembang, tidak baik $=1$

g. Pemerintah Desa melaksanakan forum penyuluhan (musyawarah kontak tani) kepada anggota kelompok tani, dengan skor :

1. Pemerintah Desa melaksanakan forum penyuluhan (musyawarah kontak tani) kepada anggota kelompok tani, baik $=3$

2. Pemerintah Desa melaksanakan forum penyuluhan (musyawarah kontak tani) kepada anggota kelompok tani, cukup baik $=2$

3. Pemerintah Desa melaksanakan forum penyuluhan (musyawarah kontak tani) kepada anggota kelompok tani, tidak baik $=1$

Dinyatakan baik dengan skor tiga, jika responden melakukan kedelapan peran di atas lebih dari tiga kali dalam seminggu, selanjutnya dinyatakan cukup baik dengan skor dua, jika responden melakukan kedelapan peran di atas hanya dibawah tiga kali dalam seminggu, dan jika responden tidak melakukan kedelapan peran di atas dinyatakan tidak pernah dengan skor satu.

Penentuan penilaian baik buruknya peran pemerintah desa terhadap kelompok tani karya lestari berdasarkan total skor dari keseluruhan responden dari masing-masing indikator peran pemerintah desa, sebagai berikut :

Jumlah responden $\mathrm{x}$ Jumlah pertanyaan x Skor terpilih

$15 \times 7 \times 3=315$

$15 \times 7 \times 2=210$

$15 \times 7 \times 1=105$

Jumlah Skor $241-360=$ Sangat Baik

Jumlah Skor $106-240=$ Cukup Baik

Jumlah Skor 0 - $105=$ Tidak Baik

Jika skor yang didapat masuk diantara 241 360, maka dapat disimpulkan bahwa peran pemerintah desa terhadap kelompok tani dikatakan Sangat Baik, selanjutnya jika skor yang didapat masuk antara 106 - 240, maka dapat disimpulkan bahwa peran pemerintah desa terhadap kelompok tani tergolong cukup baik, dan jika skor yang didapat diantara 0 105, maka dapat disimpulkan bahwa peran pemerintah desa terhadap kelompok tani tergolong kurang baik.

\section{Metode Analisis Data}

Metode analisis data yang digunakan dalam penelitian ini adalah metode deskriptif, dimana metode analisis ini mendeskripsikan setiap data yang diambil untuk menarik kesimpulan.

Untuk mengukur indikator penelitian yang digunakan dilakukan pengukuran dengan cara menguraikan indikator-indikator variabel dalam bentuk item-item pertanyaan yang disusun dalam bentuk kuesioner dengan bobot nilai (skor) jawaban 1-3, untuk membantu analisa digunakan skor dengan kategori Tinggi (skor 3), Sedang (skor 2), Rendah (skor 1) (Riduwan dalam Mamahit, 2016).

\section{HASIL DAN PEMBAHASAN}

\section{Deskripsi Wilayah Penelitian}

Sejarah Desa Talikuran Satu

Nenek moyang masyarakat Sonder berasal dari Kiawa yang datang sekitar tahun 1100 yang dipimpin oleh Dotu Najoan dan Dotu 
Sendow dan menempati hamparan yang diberi nama Rama. Kemudian mereka berpindah lagi ke Utara, tempat yang baru ini kemudian dikenal dengan nama Mawale, dari Mawale mereka berpindah lagi ke Utara ke tempat yang kemudian dikenal dengan nama Kekeseen (sekarang sekitar SD Inpres Talikuran). Dari Kekeseen masyarakat Sonder mulai berpencar-pencar dan mendirikan pemukiman-pemukiman baru.

Setelah terjadi perpisahan maka tempat yang ditinggalkan ini mereka sebut Pinetalicuran yang artinya tempat berpisah / tempat yang ditinggalkan (dari kata dasar Licur = belakang, Licuran menjadi Pinetalicuran $=$ tempat berpisah / tempat yang ditinggalkan). Lama kelamaan nama ini disebut "Talicuran", setelah pemerintah Belanda mengakui/ meresmikan desa-desa di Kecamatan Sonder yaitu pada saat pemerintah Belanda meresmikan Desa Sonder kira-kira 1837 maka kata/nama "Talicuran" diubah menjadi "Talikuran" dan pusat pemerintahan Sonder waktu itu adalah Talikuran.

Terbentuknya Desa Talikuran I berdasarkan pemekaran Desa Talikuran pada tahun 2012 di masa pemerintahan Hukum Tua Yerry Tambuwun. Desa Talikuran I termasuk di 19 Desa yang ada di Kecamatan Sonder dan merupakan Desa yang masih berumur muda.

\section{Letak Geografis}

Desa Talikuran Satu adalah sebuah desa yang terletak di wilayah Kecamatan Sonder, Kabupaten Minahasa, Provinsi Sulawesi Utara, terdiri dari $3 \mathrm{Jaga/Dusun}$ dengan batas wilayah sbb :

- Sebelah utara berbatasan dengan Desa Rambunan

- Sebelah timur berbatasan dengan Desa Talikur

- Sebelah selatan berbatasan dengan Desa Kauneran Satu

- Sebelah barat berbatasan dengan Desa Tincep

Luas wilayah Desa Talikuran Satu memanjang dari timur ke barat dengan luas 102 Hektar, beriklim tropis dan berada pada ketinggian 565 meter diatas permukaan laut sehingga Desa Talikuran Satu termasuk daerah dataran tinggi di Minahasa.

\section{Keadaan Penduduk}

Jumlah penduduk yang ada di Desa Talikuran Satu sebanyak 522 jiwa, dengan jumlah kepala keluarga sebanyak 212 KK.

\section{Deskripsi Kelompok Tani}

Kelompok Tani karya Lestari berdiri pada tahun 2007 yang dibentuk oleh sekumpulan petani yang ingin maju dan membentuk wadah kelompok ini. Alasan lain dibentuknya kelompok tani ini yaitu supaya para petani dapat berdiskusi tentang pertanian dan banyak mendapat informasi yang baru. Kelompok tani ini dibentuk sebelum dimekarkan menjadi Desa Talikuran Satu.

Kelompok Tani ini memiliki tujuan sebagai berikut :

a. Meningkatkan produktivitas usaha anggota kelompok dengan menerapkan teknologi yang tepat dan memanfaatkan sumber daya alam secara optimal.

b. Kerjasama sama kelompok yang mencerminkan tingkat produktivitas usaha para anggota.

c. Partisipasi anggota dalam kegiatan secara demokratis.

d. Pendidikan, pelatihan, dan informasi.

e. Kerjasama antar kelompok.

f. Kepedulian terhadap sesama anggota kelompok dan masyarakat lain.

Kelompok tani ini menanam dua jenis tanaman yaitu padi sawah dan jagung. Alasan mereka memilih kedua jenis tanaman ini untuk dijadikan usaha tani mereka adalah padi sawah merupakan salah satu bahan pokok pangan yang bisa diolah menjadi nasi dan didukung dengan Wilayah mereka yang berada di daerah dataran tinggi (565 meter diatas permukaan laut) sehingga banyak sumber airnya.

Jagung merupakan salah satu komoditi pangan pokok, dalam industri pangan jagung bisa dimanfaatkan sebagai pengganti beras dengan cara diolah menjadi nasi jagung, bubur jagung, dan aneka kuliner jagung lainnya karena jagung memiliki kandungan karbohidrat yang cukup tinggi dan baik untuk di konsumsi, dan yang terpenting jagung adalah bahan pokok dalam pembuatan pakan ternak, karena di Talikuran Satu dan beberapa desa yang ada di Kecamatan Sonder banyak masyarakat yang memiliki ternak sehingga inilah yang membuat usaha menanam jagung bisa sangat menguntungkan. 


\section{Karakteristik Responden}

Pendidikan sangat penting dalam usaha peningkatan kualitas seseorang serta peningkatan intelektual dan untuk menambah ilmu pengetahuan dan wawasan seseorang. Kemampuan bekerja atau melakukan aktifitas secara fisik bahkan dengan cara berpikir seseorang sangat dipengaruhi oleh factor umur. Demikian juga dengan para petani dalam melakukan pekerjaannya, dimana mereka yang berumur muda kondisi fisiknya lebih kuat dari yang berumur tua.

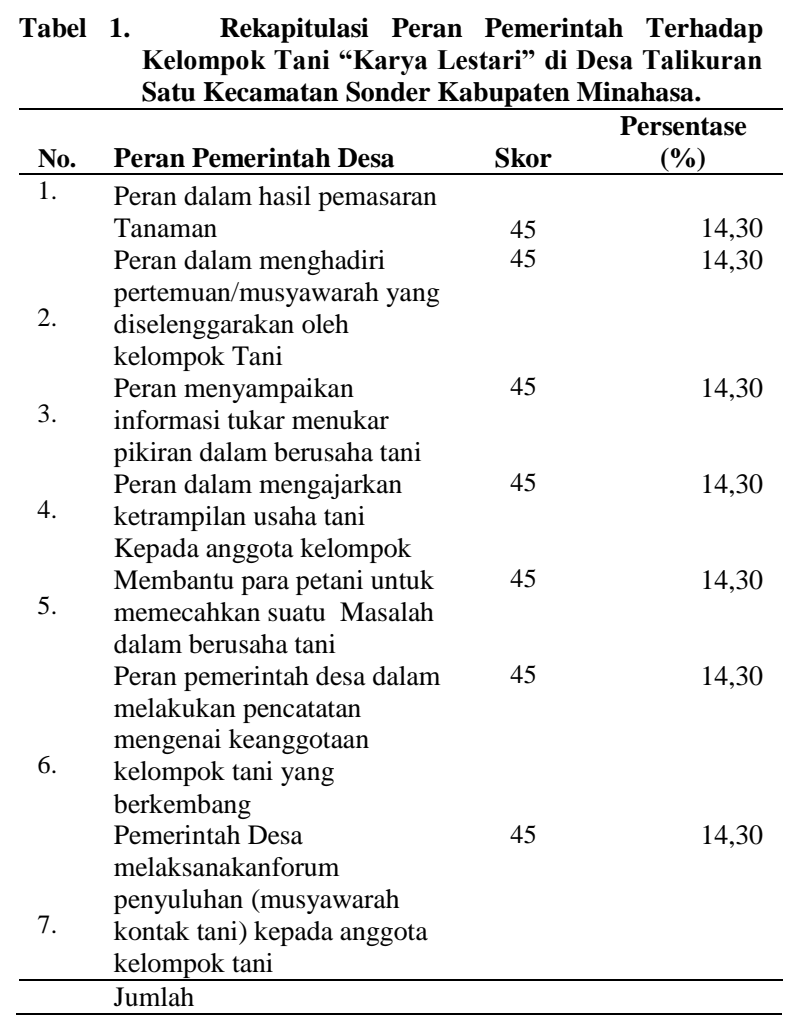

Tabel 1 menunjukkan bahwa pada indikator pertama yaitu Peran dalam hasil pemasaran tanaman mendapatkan skor 45 (14,30\%), pada indikator kedua yaitu Peran dalam menghadiri pertemuan/musyawarah yang diselenggarakan oleh kelompok tani skor 45 (14,30\%), pada indikator ketiga yaitu Peran menyampaikan informasi tukar menukar pikiran dalam berusaha tani skor 45 $(14,30 \%)$, pada indikator keempat yaitu Peran dalam mengajarkan ketrampilan usaha tani kepada anggota kelompok skor 45 (14,30\%), pada indikator kelima yaitu membantu para petani untuk memecahkan suatu masalah dalam berusaha tani skor $45(14,30 \%)$, pada indikator keenam yaitu Peran pemerintah desa dalam melakukan pencatatan mengenai keanggotaan kelompok tani yang berkembang skor $45(14,30 \%)$, dan yang terakhir indikator ketujuh yaitu Pemerintah desa melaksanakan forum penyuluhan kepada anggota kelompok tani skor $45(14,30)$ Diambil penilai baik buruknya peran pemerintah desa, sebagai berikut:

Jumlah responden $\mathrm{x}$ Jumlah pertanyaan $\mathrm{x}$ Skor terpilih

$15 \times 7 \times 3=315$

$15 \times 7 \times 2=210$

$15 \times 7 \times 1=105$

Jumlah Skor $241-360=$ Sangat Baik

Jumlah Skor $106-240=$ Cukup Baik

Jumlah Skor 0 - $105=$ Tidak Baik

Berdasarkan hasil analisis deskriptif maka dapat diketahui bahwa angka indeks peran pemerintah desa tergolong Sangat Baik dengan skor yang didapat yaitu 315. Kesimpulan secara keseluruhan dari penelitian ini tergambar dalam rekapitulasi jumlah skor tiap kategori peran.

\section{KESIMPULAN DAN SARAN}

\section{Kesimpulan}

Hasil penelitian menunjukkan bahwa peran pemerintah desa terhadap Kelompok Tani karya Lestari di Desa Talikuran Satu Kecamatan Sonder Kabupaten Minahasa tergolong sangat baik dan berperan dalam memberikan hasil pemasaran tanaman, dalam menghadiri pertemuan/musyawarah, tukar menukar pikiran dalam berusaha tani, berperan dalam mengajarkan ketrampilan dalam berusaha tani, berperan dalam melakukan pencatatan keanggotaan kelompok tani yang berkembang, dan melaksanakan forum penyuluhan untuk anggota kelompok tani. 


\section{Saran}

Pemerintah desa lebih meningkatkan lagi perannya untuk kepentingan anggota kelompok tani dalam hal mulai dari mengajarkan keterampilan berusaha tani sampai pada melakukan pecatatan keanggotaan kelompok supaya menjadi kelompok tani yang berkembang dan maju di Desa Talikuran Satu.

\section{DAFTAR PUSTAKA}

2000. Undang-Undang Nomor 72 tentang Desa.

Adisasmita. 2011. Peran Pemerintah Desa Dalam Pemberdayaan Masyarakat Petani Jagung di Desa Iloheluma Kecamatan Boliyohuto. Skripsi. gorontalo.

Agustina dan Lidya. 2011. Pengaruh Konflik Peran, Ketidakjelasan Peran, dan Kelebihan Peran Terhadap Kepuasan Kerja dan Kinerja Auditor. Penelitian Pada Kantor Akuntan Publik yang Bermitra Dengan Kantor Akuntan Publik Big Four. Jakarta.

Anonim. 2004. Undang-Undang Nomor 32 tentang Pemerintah Daerah.

Athoilah. 2010. Pemerintahan di Daerah dan Pemerintahan Desa. Alumni. Bandung.

Damima V. 2001. Dinamika Kelompok Tani Padi Sawah di Kecamatan Tondano Kabupaten Minahasa. Skripsi. Fakultas Pertanian Universitas Sam Ratulangi.
Hermanto. 2007. Rancangan Kelembagaan Tani dalam Implementasi Prima Tani di Sumatera Selatan. Jurnal Analisis Kebijakan Pertanian.

Jim Ife dan Frank Tesoriero. 2008. Comunnity Development. Pustaka Belajar. Yogyakarta

Mamahit Y. 2016. Modal Sosial Pada Kelompok Tani Esawaya Di Desa Tumani Kecamatan Maesaan Kabupaten Minahasa Selatan. Skripsi. Fakultas Pertanian Universitas Sam Ratulangi.

Mardikanto.2001. Pembentukan Kelompok dan Manfaat Organisasi. Bumi Aksara. Jakarta.

Muslim A. 2009. Metodologi Pengembang Masyarakat. Teras. Yogyakarta.

Nuryanti S. 2011. Peran Kelompok Tani Dalam Penerapan Teknologi Pertanian Bogor.

Pramudya A. 2016. Budi Daya dan Bisnis Jahe Ala Adi "Si Anak Rempah". PT AgroMedia Pustaka. Jakarta.

Saragih B. 2004. Membangun Pertanian Perspektif Agribisnis. Penebar Swadaya. Bogor.

Seokanto. 2002. Sosiologi Suatu Pengantar. Gatindo. Jakarta.

Sinambela. 2010. Administrasi Pembangunan. LP3ES. Jakarta.

Supriady D. 2001. Otonomi Penyelenggaraan Pemerintahan Daerah. PT Gramedia Pustaka Utama. Jakarta.

Susanti S. 2015. Peran Pemerintah Desa Dalam Pemberdayaan Masyarakat. Jurnal Ilmu Administrasi Negara. 
Suswono. 2013. Pedoman Pembinaan Kelompok Tani Dan Gabungan Kelompok Tani. Kementrian Pertanian. Jakarta.
Widjaja. 2003. Otonomi Desa. Raja Grafindo Persada. Jakarta. 